\title{
Republicans challenge 'misuse' of scientific data by US agencies
}

\section{Internet Expo provides boost to Asia's computer networks}

\begin{abstract}
Washington. A series of Congressional hearings opens next week, designed to investigate Republican allegations of the misuse of science by the Environmental Protection Agency (EPA) - as well as by other branches of the federal government to justify new environmental regulations.

The hearings are being held by the energy and environment subcommittee of the House science committee. They will explore various politically-sensitive scientific issues, such as the carcinogenic effects of dioxins, the role of chloroflourocarbons (CFCs) in depleting the ozone layer, and the dangers of global warming.

Dana Rohrabacher (Republican, California), the highly conservative chair of the subcommittee, plans to use the hearings to seek evidence that the US government has misused scientific data to 'prove' threats
\end{abstract} from dioxins, CFCs Rohrabacher: concern and greenhouse at dioxin conclusions. gases, in order to

justify regulations that others consider unnecessary. Prominent scientists who dispute the scientific consensus on each of these issues will be called as witnesses.

The first hearing is scheduled for 13 September, and will examine how the EPA carried out earlier this year an important reassessment of the risk of contracting cancer from exposure to dioxins. Rohrabacher's staff are particularly concerned about how the EPA completed the reassessment.

According to Harlan Watson, staff director of the subcommittee, the eight chapters in the body of the report were properly peer-reviewed. But the ninth, summarizing the report, was "written in-house by EPAtypes, and not properly peer-reviewed". bacher's subcommittee plans a hearing on the accelerated phase-out of CFCs, the solvents which were banned after scientists had established their role in depleting the ozone layer in the upper atmosphere. Witnesses include what Watson calls "some pretty sceptical folks" - including scientists who still dispute the need for the ban.

No date has been scheduled for the third hearing in the series, which will question the need for international agreements on the stabilization of greenhouse gas emissions. Rohrabacher has previously described global warming as "liberal claptrap", and is expected to track down witnesses who share his view.

Colin Macilwain
A week later, on 20 September, Rohra-

Tokyo. Asian governments are leaping eagerly at the chance to participate in next year's Internet World Exposition in Seoul, the capital of South Korea. Many see the exposition as a golden opportunity to persuade their citizens of the importance of computer-based communication.

Last week South Korea's Minister for Information and Communications, Kyong Sang-Hyon, announced his country's official support for the fair. Japan's preparations are already well advanced, China, Singapore and Thailand have recently announced they plan to participate, and other countries in the region, including Malaysia, are expected to follow suit.

The exposition, the brainchild of cyberspace pioneers such as Vinton Cerf, will run from January to December 1996, and is an attempt to emulate past world fairs, which many see as starting with the 1851 Great Exhibition at the Crystal Palace in London.

One of the achievements of such fairs has been to introduce millions of people to the latest marvels of science and technology, such as electric light and power. The Internet Expo is similarly intended to demonstrate the enormous benefits of computer connectivity, and has already won the support of the Clinton administration.

Asia currently lags far behind the United States and Europe in terms of network infrastructure and number of on-line subscribers. "Just for Japan, the expo will increase connectivity by ten times," predicts Carl Malamud, one of the fair's principal organizers, who has been travelling around Asia, signing up participants.

South Korea has designated its National Computerization Agency as the secretariat for the expo. Japan has yet to issue a formal statement of support. But in terms of fundraising and corporate backing, Japanese efforts are currently the most enthusiastic.

International telecommunications carrier $\mathrm{KDD}$, for example, has agreed to donate a high-speed T3 optical fibre link, capable of transmitting 45 megabits a second, for transPacific connection to the United States, for

\section{Europe agrees closer research links with Israel}

Paris. The council of ministers of the European Union (EU) and the government of Israel are scheduled to sign a trade agreement next month, which will allow Israel to take part in the EU's Framework research programmes.

Agreement had been expected last spring, but had been delayed because of wider negotiations over trade issues (see Nature 375, 723; 1995). Under a draft agreement whose contents were approved the duration of the expo. At the same time NTT, Japan's largest domestic carrier, will provide similar connections to 15 sites -10 cities and 5 universities - in Japan.

To encourage the participation of individual users, NTT will also set up free digital links to 300 Japanese homes. These will run at 128 kilobits per second, the fastest speed that conventional copper cables can handle.

Manufacturing companies such as Sony, as well as leading Japanese software houses like ASCII and Softbank, have pledged cash, equipment and manpower worth US $\$ 10$ million. A meeting of the Japanese expo working committee last week in Tokyo attracted almost 100 participants. The committee is chaired by Jun Murai, an associate professor at Keio University and the de facto leader of the Internet community in Japan.

Last month, Murai went to China to stimulate support for the fair. "Chinese universities are very interested in working with us," he says. Murai returned from Beijing with a memorandum of understanding signed by the vice president of the Chinese Academy of Sciences, Lu Xiankui, stating that China will participate.

As China lacks high-speed optical fibre links, Murai has arranged to borrow a transponder on JCSAT-II, a new satellite launched by Japan on 29 August. The transponder's 18 circuits, each operating at a speed of 2 megabits per second, will also provide connections with India and other parts of Asia.

A high-speed link connecting Japan and South Korea is also under discussion. All these connections could well constitute what Asia has lacked so far, namely a transcontinental Internet 'backbone'. Asian countries currently hook up to the Internet via separate links to the United States.

The expo will last for just a year. But it is likely to be of lasting significance for Asia. Malamud points out that the high-speed backbone network set up by the National Science Foundation was only temporary, but the commercial Internet developed out of it.

Bob Johnstone

during the summer, Israel also won a concession from the EU allowing it to sit on the committees that administer research programmes, even though Israel will not have voting rights on these committees.

Following next month's signing of the trade agreement - which Israel hopes will help reduce its $\$ 8$ billion trade deficit with the EU - the text will need to be approved by the European Parliament and ratified by the parliaments of all EU member states. 